\title{
Influence of application techniques on the ecotoxicological effects of nanomaterials in soil
}

\author{
Kerstin Hund-Rinke*, Karsten Schlich and Thorsten Klawonn
}

\begin{abstract}
Background: In terrestrial ecotoxicological tests, the availability and ecotoxicity of solid nanomaterials may depend on the application technique. We compared five spiking procedures using solid uncoated $\mathrm{TiO}_{2}$ and $\mathrm{Ag}$ nanoparticles in standardized OECD tests with earthworms, plants and soil microflora: dry spiking of soil by applying soil or silica sand as a carrier; dry spiking of food without a carrier; and wet spiking of soil and food with an aqueous nanoparticle dispersion.

Results: The effects of the nanomaterials were influenced by the application technique. The differences were independent of the test organism (which represented different habitats and exposure pathways) and the specificity of the effect (stimulation or inhibition). Wet spiking resulted in stronger effects than dry spiking, but the bioavailability of the particles appeared to be limited when highly-concentrated nanoparticle suspensions were used for wet spiking. The availability of the nanoparticles was slightly lower when silica sand rather than soil was used as the carrier for dry spiking, but the matrix itself (soil or food) had no effect.

Conclusion: There are indications that the concentrations of the stock suspensions influence the test results, so dry spiking is preferred for solid $\mathrm{TiO}_{2}$ and $\mathrm{Ag}$ nanoparticles. We achieved satisfactory spiking homogeneity with Ag nanoparticles using soil as a solid carrier. Further experiments with other carriers and soil types are required to confirm that the observed differences are universal in character. There was no difference in effect when $\mathrm{TiO}_{2}$ nanoparticles were applied via food or soil. The spiking of soil instead of food is preferred for $\mathrm{TiO}_{2}$ nanoparticles, as is the case for conventional chemicals.
\end{abstract}

Keywords: $\mathrm{TiO}_{2}$ nanoparticles, Ag nanoparticles, Terrestrial ecotoxicity, Soil application method

\section{Background}

The increasing use of nanotechnology means that nanomaterials will inevitably enter the environment. Ecotoxicological data are required for risk assessments, and a preliminary review concerning the application of OECD guidelines to manufactured nanomaterials [1] stated that the basic practices recommended by these guidelines are suitable for the testing of nanomaterials. However, guidelines for the delivery of substances to test systems, the quantitation of exposure, and the dose metrics, need to be adapted for the testing of nanomaterials. The guidance for sample preparation and dosimetry for the safety testing of manufactured nanomaterials does not provide detailed instructions for the application

\footnotetext{
* Correspondence: kerstin.hund-rinke@ime.fraunhofer.de

Fraunhofer Institute for Molecular Biology and Applied Ecology, Auf dem Aberg 1, 57392, Schmallenberg, Germany
}

of nanomaterials in aqueous or non-aqueous media, but principal procedures are listed [2].

The guidance also state that nanomaterials applied to solid test media such as soils and sediments can be introduced by dispersion or in solid form, although the application method should be carefully chosen to avoid damaging the test substance. For example, the use of high-energy ultrasonication to achieve homogenous aqueous dispersions, or the use of a mortar and pestle to mix solid material with a solid carrier such as silica sand or soil, may damage or modify the surface, coating or crystalline structure of the nanomaterial. The waterbased dispersion of nanomaterials is recommended to provide comparability between aquatic, terrestrial and sediment tests [2].

Several application methods have been proposed, including the application of nanomaterial suspensions to the soil [3-8] or to food which is then added to the soil 
$[8,9]$, and the application of nanoparticle powder directly to the soil [5,10-12]. The details of the methods may vary in terms of the substrate, e.g. application to dry [6] or wet soil [7], or the dispersion technique, e.g. $\mathrm{TiO}_{2}$ can be dispersed by vortexing in water before adding to air-dried soil [6] or by vigorous stirring for $10 \mathrm{~min}$ and sonicating for $30 \mathrm{~min}$, followed by drop wise addition to the soil with no further homogenization [7]. The nanomaterial concentrations in the suspensions can also vary widely, e.g. nominal concentrations between $600 \mathrm{mg} / \mathrm{L} \mathrm{[5]} \mathrm{and} 20 \mathrm{~g} / \mathrm{L}$ [7] have been reported in the case of $\mathrm{TiO}_{2}$. Solvents may be added to increase the stability and homogeneity of the suspensions before spiking soil with carbon-based nanomaterials such as fullerene $[3,4]$. For $\mathrm{TiO}_{2}$, sodium hydroxide may be added to the stock suspension to increase the $\mathrm{pH}$ to $10[5,6]$.

It is well known that nanomaterial properties such as the zeta potential, agglomeration size, deposition and resuspension behavior depend on environmental conditions [13-17]. The application technique may therefore affect the behavior and availability of nanomaterials and consequently their overall effect on soil organisms. Although application methods have been compared systematically for aquatic tests [18-20], equivalent comparisons have not yet been carried out for soil tests.

We therefore compared five different application methods to determine their impact on the measured terrestrial ecotoxicity of $\mathrm{TiO}_{2}$ and Ag nanoparticles towards earthworms, plants and soil microflora. Ecotoxicological tests were carried out according to standardized test guidelines using natural soil [21-24]. The application procedures are summarized in Table 1. We spiked the soil with either nanomaterial powders (using either soil or silica sand as the carrier) or aqueous nanomaterial dispersions. In the earthworm tests, we also investigated the effects of exposure via spiked food (powder or aqueous dispersion). The individual tests focused on different aspects of nanomaterial exposure scenarios. Not every approach was investigated in all test systems but the results could be combined. The aim of this study was to support the interpretation and comparison of ecotoxicological tests involving different application techniques, and to determine the most suitable application techniques for such tests.

Table 1 Applied spiking procedures

\begin{tabular}{llc}
\hline Principle of spiking & Carrier & Spiked matrix \\
\hline Dry (powder) & Soil & Soil \\
\hline Dry (powder) & Silica sand & Soil \\
\hline Dry (powder) & No carrier & Food \\
\hline Wet (dispersion) & Deionized water & Soil \\
\hline Wet (dispersion) & Deionized water & Food \\
\hline
\end{tabular}

\section{Results}

To ensure the clarity of presentation, we first describe the effects achieved with different application methods within each test system, and then summarize the results focusing on the application methods.

\section{Effects of different application methods in individual ecotoxicological tests}

We used nanoparticle concentrations of up to $200 \mathrm{mg} / \mathrm{kg}$ soil dry mass $(\mathrm{dm})$ for dry spiking, and concentrations of 100 and $200 \mathrm{mg} / \mathrm{L}$ for wet spiking dispersions, resulting in soil concentrations of 10 and $20 \mathrm{mg} / \mathrm{kg} \mathrm{dm}$. The maximum concentrations used for wet spiking were limited by the maximum water holding capacity $\left(\mathrm{WHC}_{\max }\right)$ of the soil and by the maximum concentrations suitable for the stock dispersions. The $\mathrm{WHC}_{\max }$ limits the maximum amount of water that can be added to achieve a water content suitable for ecotoxicological testing. Dispersions with nanoparticle concentrations higher than the maximum $200 \mathrm{mg} / \mathrm{L}$ we used were considered unsuitable because this resulted in immediate sedimentation, reflecting the formation of large agglomerates. We investigated the effects of wet and dry spiking with soil as the carrier in tests using plants, earthworms and microbes (nitrogen transformation). We also compared dry spiking with soil and silica sand carriers by considering the potential ammonium oxidation activity.

\section{Plant test}

In the plant test with $\mathrm{TiO}_{2}$ nanoparticles (Table 2), we compared wet and dry applications with soil as the carrier. Neither the powdered test substance nor the dispersion had a significant impact on germination (data not shown). The powder application showed a concentration-dependent effect on above-ground biomass, but only the highest concentration $(100 \mathrm{mg} / \mathrm{kg} \mathrm{dm})$ resulted in a statisticallysignificant reduction compared to the control (30\%) resulting in a NOEC value of $67.0 \mathrm{mg} / \mathrm{kg} \mathrm{dm}$. For the dispersed nanoparticles, the lower concentration $(10 \mathrm{mg} / \mathrm{kg}$ $\mathrm{dm}, 18 \%$ compared to the control) caused a slightly stronger and statistically-significant effect than the higher concentration $(20 \mathrm{mg} / \mathrm{kg} \mathrm{dm}, 12 \%$ compared to the control). NOEC values were not calculated because of the limited number of test concentrations and the absence of a concentration-effect relationship.

\section{Nitrogen transformation test}

For the nitrogen transformation test (Table 3), we compared wet and dry applications with soil as the carrier. The short $(3 \mathrm{~h})$ incubation period after the dry application procedure resulted in a concentration-dependent reduction in nitrate levels of up to $21 \%$ compared to the control. However, this trend was reversed after 28 days, resulting in higher nitrate levels (up to 20\% compared to 
Table $2 \mathrm{TiO}_{2}$ (P25) - Plant test: fresh weight of the shoots

\begin{tabular}{ll}
\hline${\text { Test concentration }\left[\mathbf{m g} / \mathbf{k g}{ }^{\mathbf{1}}\right.}^{{ }^{1}}$ & $\begin{array}{l}\text { Avena sativa Fresh } \\
\text { weight } \pm \text { SD }^{2} \text { [g/kg] }\end{array}$ \\
\hline 0 (control) & $2.591 \pm 0.286$ \\
\hline Application via powder $[\mathrm{mg} \mathrm{TiO2/kg]}$ & $2.571 \pm 0.487$ \\
\hline 10 & $2.461 \pm 0.279$ \\
\hline 20 & $2.567 \pm 0.391$ \\
\hline 30 & $2.382 \pm 0.329$ \\
\hline 44 & $2.200 \pm 0.185$ \\
\hline 100 & $1.803 \pm 0.204^{*}$ \\
\hline Application via dispersion & \\
\hline 10 & $2.130 \pm 0.201{ }^{*}$ \\
\hline 20 & $2.286 \pm 0.368$ \\
\hline
\end{tabular}

${ }^{1}$ All concentrations refer to soil dry mass. ${ }^{2}$ SD: standard deviation. Asterisks indicate a statistically significant difference to control (significance $a=0.05$; one-sided smaller, Williams multiple sequential t-test).

the control) at higher concentrations of $\mathrm{TiO}_{2}(100 \mathrm{mg} /$ $\mathrm{kg})$. The concentration-dependent nitrogen transformation rates resulted in a NOEC of $9.3 \mathrm{mg} / \mathrm{kg} \mathrm{dm}$. The wet application procedure resulted in a less pronounced reduction in nitrate levels (up to $2 \%$ at $10 \mathrm{mg} / \mathrm{kg} \mathrm{TiO}_{2}$ ) after $3 \mathrm{~h}$ and also in less potent stimulation after 28 days (up to $11 \%$ at $10 \mathrm{mg} / \mathrm{kg} \mathrm{TiO}_{2}$ ) in comparison to the dry application test. The nitrogen transformation rate increased compared to the control, but not to the extent observed following dry application. A NOEC value was not calculated due to the lack of concentration dependence and the limited number of test concentrations.

\section{Earthworm reproduction test}

We compared four application methods in the earthworm reproduction test (Table 4), i.e. dry and wet applications to soil and the initial food using the same amount of $\mathrm{TiO}_{2}$ per test vessel regardless of the matrix.
The $\mathrm{TiO}_{2}$ concentration in the food was therefore much higher than in the soil. Earthworm biomass increased during all the tests due to feeding (around 60\%), but there was a small yet statistically-significant difference in gained biomass compared to control vessels when we compared the dry and wet application of $10 \mathrm{mg} / \mathrm{kg} \mathrm{TiO}{ }_{2}$ nanoparticles to food (6\% for dry spiking and $8 \%$ for wet spiking). The presence of $\mathrm{TiO}_{2}$ nanoparticles also promoted reproduction (up to $57 \%$ higher compared to controls) regardless of the application method (wet or dry) or the spiked matrix (soil or food). A concentrationdependent relationship was observed for the dry spiking method which was comparable with both matrices, but the differing standard deviations resulted in NOEC values of $50 \mathrm{mg} / \mathrm{kg} \mathrm{dm}$ for spiked food and $<50 \mathrm{mg} / \mathrm{kg}$ $\mathrm{dm}$ for spiked soil. Two $\mathrm{TiO}_{2}$ concentrations were tested using the wet application method (10 and $20 \mathrm{mg} / \mathrm{kg} \mathrm{dm}$, about $50 \%$ increase in reproduction for dry spiking and $32 \%$ increase in reproduction for wet spiking of food compared to control). Both concentrations were below the concentrations used for dry spiking but resulted in a higher number of juveniles compared to the higher test concentrations of dry spiking. The higher concentration did not increase the effect of the test compound (indeed there was a marginal reduction in impact at the higher concentration) and the spiking of food rather than soil resulted in a smaller increase in the number of offspring (32\% compared to $50 \%$ ). NOEC values were not calculated due to the limited number of test concentrations.

Most $\mathrm{TiO}_{2}$ concentrations resulted in a statisticallysignificant increase in the number of juveniles compared to control vessels, but the difference was not significant in some tests because of comparable large standard deviations between replicates. For example, the dry application of $100 \mathrm{mg} \mathrm{TiO} 2$ per $\mathrm{kg} \mathrm{dm}$ to the soil did not yield a significant difference to the control because the standard deviation was 25\% (number of juveniles: $299 \pm 74$ )

Table $3 \mathrm{TiO}_{2}$ (P25) - Nitrogen transformation: nitrate content and nitrogen transformation rate

\begin{tabular}{|c|c|c|c|}
\hline \multirow[t]{2}{*}{$\begin{array}{l}\text { Test concentration } \\
{[\mathrm{mg} / \mathrm{kg}]^{1}}\end{array}$} & \multirow{2}{*}{ 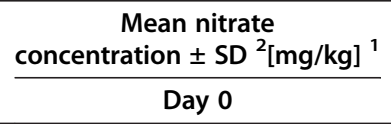 } & \multirow{2}{*}{ 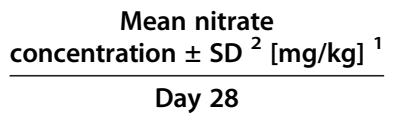 } & \multirow[t]{2}{*}{$\begin{array}{c}\text { Nitrogen transformation } \\
\text { rate } \pm \mathrm{SD}^{2}[\mathrm{mg} /(\mathbf{k g} * 28 \mathrm{~d})]\end{array}$} \\
\hline & & & \\
\hline Control & $27.3 \pm 1.1$ & $32.6 \pm 3.4$ & $5.4 \pm 2.7$ \\
\hline \multicolumn{4}{|c|}{ Application via powder } \\
\hline 9.3 & $27.2 \pm 2.8$ & $35.9 \pm 2.9$ & $9.6 \pm 2.7$ \\
\hline 21 & $24.7 \pm 1.7^{*}$ & $35.8 \pm 2.0$ & $11.1 \pm 1.5^{*}$ \\
\hline 45 & $21.7 \pm 2.6^{*}$ & $36.8 \pm 4.0$ & $15.1 \pm 4.3^{*}$ \\
\hline 100 & $21.5 \pm 3.4^{*}$ & $39.3 \pm 2.5^{*}$ & $17.8 \pm 5.7^{*}$ \\
\hline \multicolumn{4}{|c|}{ Application via dispersion } \\
\hline 9.3 & $27.8 \pm 2.8$ & $36.2 \pm 4.9$ & $8.3 \pm 2.3$ \\
\hline 21 & $26.0 \pm 4.1$ & $34.1 \pm 1.3$ & $8.1 \pm 3.9$ \\
\hline
\end{tabular}

${ }^{1}$ All concentrations refer to soil dry mass. ${ }^{2}$ SD: standard deviation. Asterisks indicate a statistically significant difference to control (significance $a=0.05$; onesided smaller, Williams multiple sequential t-test). 
Table 4 Effects of $\mathrm{TiO}_{2}$ (P25) in the earthworm reproduction test

\begin{tabular}{|c|c|c|c|c|c|}
\hline $\begin{array}{l}\text { Test concentration } \\
{[\mathrm{mg} / \mathrm{kg}]^{1}}\end{array}$ & $\begin{array}{l}\text { Mortality } \\
{[\%]}\end{array}$ & $\begin{array}{l}\text { Mean biomass per vessel } \\
\text { at test start } \pm \mathrm{SD}^{2}[\mathrm{~g}]^{1}\end{array}$ & $\begin{array}{l}\text { Biomass per vessel } \\
\text { at test end } \pm \mathrm{SD}^{2}[\mathrm{~g}]^{1}\end{array}$ & $\begin{array}{l}\text { Increase in biomass of adult } \\
\text { worms after } 28 \mathrm{~d}[\%]^{3}\end{array}$ & $\begin{array}{l}\text { Number of juveniles } \\
\text { per test vessel } \pm \text { SD }^{2}\end{array}$ \\
\hline 0 (control) & 0 & $3.29 \pm 0.24$ & $5.47 \pm 0.36$ & 67 & $212 \pm 46$ \\
\hline \multicolumn{6}{|c|}{ Application via powder on soil } \\
\hline 50 & 0 & $3.37 \pm 0.43$ & $5.80 \pm 0.15$ & 74 & $295 \pm 44 *$ \\
\hline 100 & 0 & $3.49 \pm 0.13$ & $5.47 \pm 0.10$ & 57 & $299 \pm 74$ \\
\hline 200 & 0 & $3.45 \pm 0.14$ & $5.47 \pm 0.11$ & 59 & $315 \pm 42$ \\
\hline \multicolumn{6}{|c|}{ Application via powder on food } \\
\hline 50 & 0 & $3.36 \pm 0.25$ & $5.48 \pm 0.32$ & 63 & $280 \pm 84$ \\
\hline 100 & 0 & $3.17 \pm 0.26$ & $5.41 \pm 0.33$ & 71 & $309 \pm 67 *$ \\
\hline 200 & 0 & $3.29 \pm 0.27$ & $5.37 \pm 0.33$ & 63 & $333 \pm 71 *$ \\
\hline \multicolumn{6}{|c|}{ Application via dispersion on soil } \\
\hline 10 & 0 & $3.25 \pm 0.12$ & $5.15 \pm 0.12$ & $58 *$ & $326 \pm 74 *$ \\
\hline 20 & 0 & $3.33 \pm 0.25$ & $5.69 \pm 0.15$ & 71 & $321 \pm 14 *$ \\
\hline \multicolumn{6}{|c|}{ Application via dispersion on food } \\
\hline 10 & 0 & $3.23 \pm 0.09$ & $5.04 \pm 0.10$ & $56 *$ & $280 \pm 52$ \\
\hline 20 & 0 & $3.21 \pm 0.16$ & $5.26 \pm 0.13$ & 64 & $279 \pm 12$ \\
\hline
\end{tabular}

whereas the application of $50 \mathrm{mg} / \mathrm{kg}$ resulted in a statistically significant difference, reflecting the smaller standard deviation of $15 \%$ (number of juveniles: $295 \pm 44$ ).

Table 5 shows the effect of $\mathrm{Ag}$ and $\mathrm{TiO}_{2}$ nanoparticles on ammonium oxidation activity in the soil using soil or silica sand as carrier. In both cases, application via spiked soil had a greater impact than application via spiked silica sand (100 mg/kg Ag: soil 94\%, silica sand 69\% reduction compared to the control; $100 \mathrm{mg} / \mathrm{kg} \mathrm{TiO}$ : soil $27 \%$, silica sand $0 \%$ reduction compared to the control). Only the $100 \mathrm{mg} / \mathrm{kg}$ treatments resulted in statistically-significant deviations compared to the control.

The effect of different spiking procedures

The overall conclusion from the ecotoxicological tests was that regardless of the test organism and the effect of

Table 5 Effect of $\mathrm{TiO}_{2}$ and silver nanoparticles on microbial ammonium oxidation activity

\begin{tabular}{|c|c|c|}
\hline $\begin{array}{l}\text { Test } \\
\text { concentration } \\
\text { [mg/kg] }^{1}\end{array}$ & $\begin{array}{l}\text { Ag nanoparticles } \\
\text { Microbial ammonium } \\
\text { oxidation activity } \pm \\
\text { SD }^{2}\left[\mathrm{ng} /\left(g^{*} h\right)\right]^{1}\end{array}$ & $\begin{array}{l}\mathrm{TiO}_{2} \text { nanoparticles } \\
\text { Microbial ammonium } \\
\text { oxidation activity } \pm \\
\mathrm{SD}^{2}\left[\mathrm{ng} /\left(\mathrm{g}^{*} \mathrm{~h}\right)\right]^{1}\end{array}$ \\
\hline 0 (control) & $50.9 \pm 8.3$ & $25.7 \pm 5.6$ \\
\hline $10 \mathrm{mg} / \mathrm{kg}$ via soil & $47.0 \pm 3.6$ & $23.6 \pm 1.0$ \\
\hline $\begin{array}{l}10 \mathrm{mg} / \mathrm{kg} \text { via silica } \\
\text { sand }\end{array}$ & $50.4 \pm 6.3$ & $24.5 \pm 1.8$ \\
\hline $100 \mathrm{mg} / \mathrm{kg}$ via soil & $3.0 \pm 0.9 *$ & $18.8 \pm 2.7^{*}$ \\
\hline $\begin{array}{l}100 \mathrm{mg} / \mathrm{kg} \text { via silica } \\
\text { sand }\end{array}$ & $15.9 \pm 3.7^{*}$ & $26.1 \pm 7.3$ \\
\hline
\end{tabular}

${ }^{1}$ All concentrations refer to soil dry mass. ${ }^{2}$ SD: standard deviation. Asterisks indicate a statistically-significant difference (significance $a=0.05$; one-sided, Williams multiple sequential t-test). the test substance (stimulation or inhibition) only the dry application procedure using soil as the carrier generated a concentration-effect curve (Figure 1), whereas the wet application procedure did not result in a concentration-dependent effect (Figure 2). Although we only tested two nanoparticle concentrations by wet application, which limits any conclusions about concentration dependence, the mean values of nearly all the tests indicated no increase in effect at higher test concentrations. In the earthworm reproduction test, there was no significant difference between earthworms exposed to spiked soil and spiked food.

Experiments with both $\mathrm{TiO}_{2}$ and Ag nanoparticles indicated that soil was a better carrier than silica sand because the latter reduced the bioavailability of the particles (Figure 3). The difference in effect was 3-7\% at the lower test concentration $(10 \mathrm{mg} / \mathrm{kg} \mathrm{dm})$ and $25-28 \%$ at the higher test concentration $(100 \mathrm{mg} / \mathrm{kg} \mathrm{dm})$.

The homogeneity of dry spiking was confirmed by chemical analysis. After spiking $2.5 \mathrm{~kg}$ of soil with $\mathrm{Ag}$ nanoparticles using the dry spiking method and soil as the carrier, six samples were randomly collected at different locations from the spiked soil and the silver content was determined (Table 6). The standard deviation was $4 \%$ at $100 \mathrm{mg} / \mathrm{kg} \mathrm{dm}$ and $11 \%$ at $10 \mathrm{mg} / \mathrm{kg} \mathrm{dm}$.

\section{Discussion}

In our tests, we applied $\mathrm{TiO}_{2}$ and $\mathrm{Ag}$ nanoparticles at concentrations higher than those expected in the environment based on a published model predicting soil concentrations of $1.28 \mu \mathrm{g} / \mathrm{kg} \mathrm{TiO}_{2}$ and $22.7 \mu \mathrm{g} / \mathrm{kg} \mathrm{Ag}$ in 


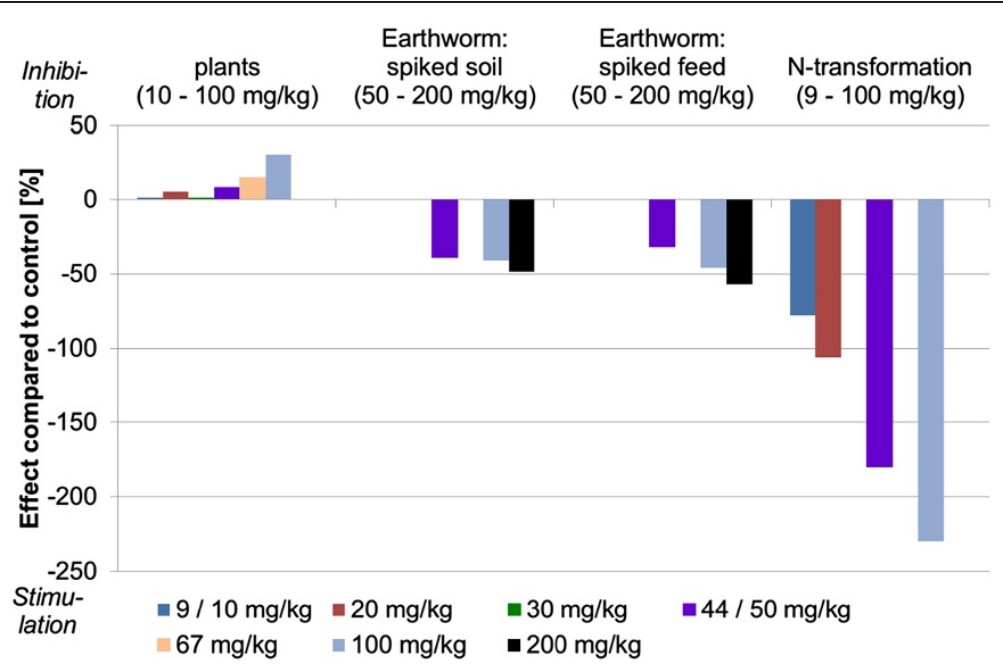

Figure 1 Effect of $\mathrm{TiO}_{2}$ applied as dry powder to soil and food. All tests (plant growth; earthworm reproduction, nitrogen transformation) were carried out according to the relevant OECD test guidelines in natural soil. The bars indicate the percent effect compared to the control at the different test concentrations. Stimulation is shown by negative values, inhibition by positive values. After the test description, the range of the test concentrations is shown in parentheses. Similar concentrations in different tests are shown in the same color (e.g. 9 and $10 \mathrm{mg} / \mathrm{kg} ; 44 \mathrm{and}$ $50 \mathrm{mg} / \mathrm{kg}$ ).

Europe [25]. Risk assessment is based on NOEC and/or $\mathrm{EC}_{50}$ values, which are reduced by assessment factors to compensate for the limited number of test organisms [26]. The use of assessment factors means that the consideration of test concentrations above environmental values is justified. Therefore, it is essential to develop procedures that allow the application of comparably high test concentrations for subsequent risk assessment.

We compared dry and wet spiking using water as dispersant. Our results clearly show that the application method can affect the ecotoxicological impact of nanomaterials, and that wet spiking can cause stronger effects than dry spiking. The wet application of $10 \mathrm{mg} /$ $\mathrm{kg}$ nanoparticles resulted in a statistically-significant differences to the control in the plant test, whereas the dry spiking approach did not. We used 10 and $20 \mathrm{mg} / \mathrm{kg}$ $\mathrm{TiO}_{2}$ concentrations for wet spiking in the earthworm tests, and the stimulatory effect was comparable to or higher than that obtained for the lowest concentration used for dry spiking $(50 \mathrm{mg} / \mathrm{kg})$. The differences in the bioavailability of the test substance may therefore reflect the different agglomeration and sorption behavior of the

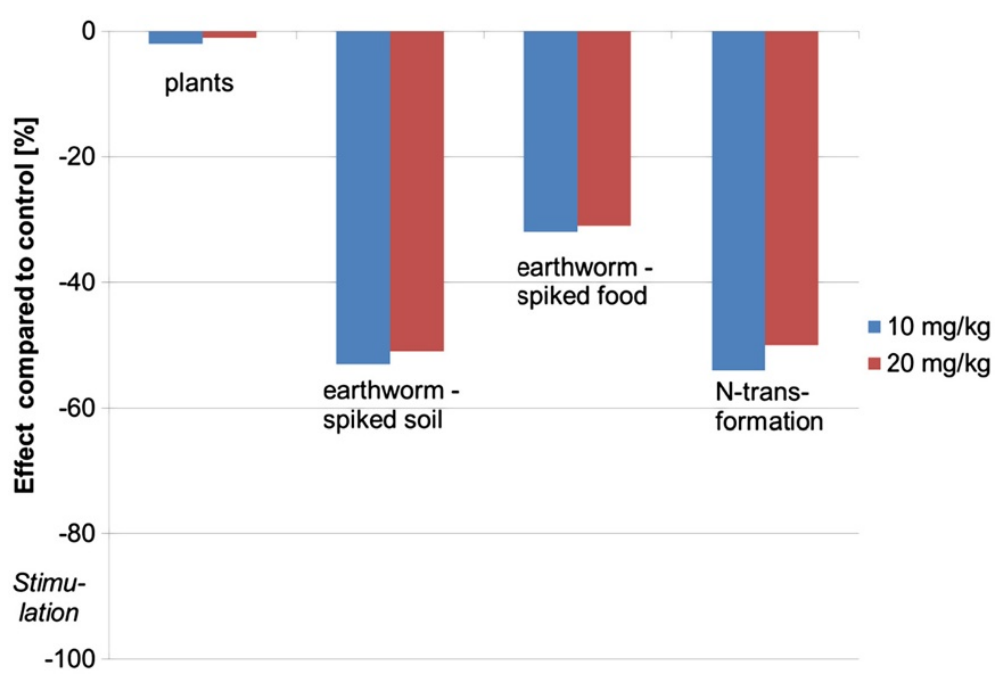

Figure 2 Effect of $\mathrm{TiO}_{2}$ applied as wet dispersions in soil and food. All tests (plant growth; earthworm reproduction, nitrogen transformation) were carried out according to the relevant OECD test guidelines in natural soil. The bars show the percent effect compared to the control. Negative values indicate stimulation. Two test concentrations $(10 \mathrm{mg} / \mathrm{kg} ; 20 \mathrm{mg} / \mathrm{kg})$ were investigated. 




Figure 3 Effect of $\mathrm{Ag}$ and $\mathrm{TiO}_{2}$ applied to the soil as dry powders using different carriers. The test (potential ammonium oxidation activity) was carried out according to the relevant ISO test guideline in natural soil. The bars show the percent effect compared to the control. Stimulation is shown by negative values, inhibition by positive values. The soil was spiked with the different nanomaterials using soil and silica sand as carriers.

nanomaterial under dry and wet spiking conditions. The characterization of nanomaterials in soil is still an important field of research and the state of the art has been recently reviewed $[27,28]$. Unless we are able to characterize nanomaterials in soil, it may be difficult to explain their differing effects and to interpret the results of spiking studies.

No concentration-effect dependence was observed when wet application methods were used, although there was a statistically significant difference between experimental and control vessels. This agrees with previous reports showing that the application of $0.5,1$ and $2 \mathrm{~g} / \mathrm{kg} \mathrm{dm} \mathrm{TiO}_{2}$ induces statistically significant but not concentration-dependent effects on microbial soil respiration [7]. Stock $\mathrm{TiO}_{2}$ concentrations of up to $20 \mathrm{~g} / \mathrm{L}$ were used in the investigation discussed above [7]. McShane et al. [5] avoided this by using an application method based on the required nanoparticle concentration in the soil. $\mathrm{TiO}_{2}$ dispersions were used only for soil concentrations up to $200 \mathrm{mg} / \mathrm{kg}$. The maximum concentration in the aqueous stock suspension was $600 \mathrm{mg} / \mathrm{L}$. Higher test concentrations were achieved by the dry application of $\mathrm{TiO}_{2}$, which was justified by the

Table 6 Homogeneity of spiking - mean values of six samples taken at different locations of the soil spiked with Ag nanoparticles (dry application with soil as the carrier)

\begin{tabular}{llcc}
\hline Nanomaterial & $\begin{array}{l}\text { Measured } \\
\text { concentration } \\
\text { [mg/kg] }\end{array}$ & $\begin{array}{c}\text { Recovery } \\
\text { [\%] }\end{array}$ & $\begin{array}{c}\text { Standard } \\
\text { deviation [\%] }\end{array}$ \\
\hline Solid $\mathrm{Ag}-100 \mathrm{mg} / \mathrm{kg}$ & $80.4 \pm 3.1$ & 80 & 3.9 \\
\hline Solid $\mathrm{Ag}-10 \mathrm{mg} / \mathrm{kg}$ & $7.5 \pm 0.8$ & 76 & 10.7 \\
\hline
\end{tabular}

${ }^{1}$ All concentrations refer to soil dry mass. physical limitations of the dispersion method (i.e. the large amounts of nanomaterials needed to create the dispersions with nominal concentrations $\geq 1000 \mathrm{mg} / \mathrm{kg}$ [5]).

For tests in aqueous media, the nanoparticle concentration in the dispersion affects the size of the resulting agglomerates, which reduces the toxicity of the nanoparticles [29,30]. Tests using Caenorhabditis elegans on agar plates resulted in the steady-state inhibition of survival despite the increasing test concentrations of Ag nanoparticles [31]. Therefore, we propose that the statisticallysignificant but concentration-independent effects of nanoparticle dispersions we observed reflect the comparable bioavailability of nanoparticles with different total concentrations due to the agglomeration behavior of nanoparticles in the stock preparation. We tested the two nanoparticle concentrations (10 and $20 \mathrm{mg} / \mathrm{L})$ based on different stock suspensions (100 and $200 \mathrm{mg} / \mathrm{L}$ ) and observed ecotoxicological effects on plants, earthworms and nitrogen-transforming microorganisms. We observed statistically-significant differences between experimental and control vessels in terms of plant growth and earthworm reproduction, although the mean values of the relevant parameters (plant fresh weight, number of juvenile earthworms) did not correspond to the differing concentrations. For example, the higher test concentrations had a lower impact on plant biomass, and the number of juvenile earthworms was similar at both test concentrations. It is possible that concentration-effect relationships could be revealed by repeating the tests at lower concentrations based on less-concentrated stock suspensions.

Ploeg et al. [32] and Kool et al. [33] observed concentration-dependent effects for $\mathrm{C} 60$ and $\mathrm{ZnO}$ even at high soil concentrations (C60: up to $154 \mathrm{mg} / \mathrm{kg}$; nano- 
$\mathrm{ZnO}$ : up to $6400 \mathrm{mg} \mathrm{Zn} / \mathrm{kg} \mathrm{dm}$ ) after applying the nanomaterials to soil using soil extracts instead of deionized water. Natural stabilizers (e.g. dissolved organic matter) in soil extracts may improve the stability and reduce the agglomeration of nanomaterials resulting in higher bioavailability. The recommendation of soil extracts for standardized tests means that the soil types and preparation methods must also be standardized, e.g. using guideline ISO 21268-1, which recommends a soil to water ratio of $1: 2$ and $24 \mathrm{~h}$ shaking [34].

Johansen et al. [4] avoided highly-concentrated C60 stock suspensions by the repeated application of a weaker suspension until the desired test concentration was achieved. Between individual applications, the soil was dried in a vacuum oven to reduce the water content before the next dose was added. However, this may promote the aging of the nanomaterial in situ, modifying the sorption and hence the availability to test organisms. For example, Schreck et al. [35] studied the effect of lead-enriched particulate matter by comparing freshly spiked, aged and long-term polluted soils. The ecotoxicity and bioavailability of the contaminated particulate matter was strongly influenced by complex interactions with the soil, and ageing was shown to reduce the toxicity of the test substance. Donner et al. [36] investigated the aging of zinc applied as $\mathrm{ZnSO}_{4}$ in field soils, and found that ${ }^{65} \mathrm{Zn}$ radioisotope dilution declined over time providing evidence of $\mathrm{Zn}$ fixation. This effect was not obvious in the ecotoxicological tests and was attributed to the strong regulatory impact of abiotic properties. Unless we are able to characterize nanomaterials in soil, it may be difficult to consider their effects and interpret the results of spiking studies using repeated drying/wetting cycles.

Dry application produced concentration-effect relationships in all the test systems. The nanomaterials were applied using a carrier. Inert carriers such as silica sand, for chemicals that are insoluble in water and organic solvents, are already described in the OECD test guidelines. We compared dry test soil and silica sand and found that effects were higher when the $\mathrm{TiO}_{2}$ and Ag nanoparticles were applied using dry test soil instead of silica sand. We assume that the bioavailability of the particles is reduced by silica sand. We only tested one soil, but this fulfilled all the criteria in the test guidelines for natural soils used as a test medium. The soil is characterized by a high content of sand (71\%), low levels of organic carbon $(0.93 \%)$ and a $\mathrm{pH}$ in the range $5.5-7.5$. The use of different soil types will determine whether silica sand always reduces the bioavailability of nanomaterials compared to natural soil (indicating that the observed difference is a universal characteristic) or whether the effect is specific to particular soil types.
The homogeneity of Ag nanoparticle powder following the spiking of carrier soil was determined by chemical analysis and we observed a low standard deviation at both test concentrations ( $4 \%$ at $100 \mathrm{mg} / \mathrm{kg} \mathrm{dm}$ and $11 \%$ at $10 \mathrm{mg} / \mathrm{kg} \mathrm{dm}$ ). The homogeneity of $\mathrm{TiO}_{2}$ spiking could not be demonstrated due to the high background level of $\mathrm{TiO}_{2}$ in the applied soil $(1.3 \mathrm{~g} / \mathrm{kg})$. To include biological variability, we selected 68 results (mean values and standard deviations) with either $\mathrm{TiO}_{2}$ or Ag nanoparticles from randomly-selected tests with different test organisms and test parameters, including earthworm reproduction, plant growth and microbial nitrogen and carbon transformation. All tests were carried out according to the appropriate OECD guidelines. Furthermore, we applied the same criteria to tests with conventional chemicals (60 test results, mean values and standard deviations). Every standard deviation was expressed as a percentage of the respective mean value. We calculated the $90 \%$ percentile of the standard deviations for both sets of tests (nanomaterials and conventional chemicals) and found that $90 \%$ of the standard deviations in the nanomaterial tests were in the range $2-17 \%$ compared to $3-24 \%$ in the conventional chemical tests. The variability of the chemical analysis results for Ag was comparable to the variability of the ecotoxicological test results with $\mathrm{Ag}$ and $\mathrm{TiO}_{2}$ nanomaterials. Furthermore, the variability of the nanomaterial tests based on dry spiking using soil as the carrier was comparable to the variability of the conventional substance tests spiked with aqueous solutions. We therefore concluded that the dry spiking procedure using soil as the carrier achieves adequate spiking homogeneity, at least for Ag and uncoated $\mathrm{TiO}_{2}$ nanoparticles.

Earthworms were exposed to the test substances via spiked soil or food using wet and dry application methods. The wet application of nanomaterials to soil had a marginal stimulating effect on reproduction compared to wet application in food, but none of the differences between the matrices was statistically significant. For dry application no obvious difference was observed. Lapied et al. [8] also compared the effect of earthworm exposure via spiked food and via soil, and attributed the absence of effects in the tests with spiked food to avoidance behavior. We did not observe avoidance of spiked food in our experiments, even though the substance concentrations in the spiked food were higher $(1272 \mathrm{mg} / \mathrm{kg} \mathrm{dm}$ for wet application compared to $100 \mathrm{mg} / \mathrm{kg} \mathrm{dm}$ in the study discussed above [8]). Feeding was implemented by spreading dung on the soil surface as recommended in the test guideline [21], thus the removal of dung by feeding was easy to verify. The biomass increase in adult worms was also a useful indicator of food uptake, and this was comparable for our spiked food and spiked soil experiments. The behavioral differences may reflect the use of uncoated 
particles in our experiments and $\mathrm{Al}_{2} \mathrm{O}_{3}$-coated particles in the previous investigation [8]. Avoidance behavior has also been reported for earthworms exposed to Ag nanoparticles indicating perception of the contaminants [37].

Both applied spiking procedures have advantages and limitations which are summarized in Table 7. There is no limitation regarding the test concentrations with dry spiking, and it is expected that the basic procedure is independent of the chemical composition of the nanomaterial. However reduced bioavailability has to be accepted because no energy is introduced to break up the agglomerates. Energy by stirring and sonication is introduced to prepare the stock dispersions for wet spiking and higher bioavailability is expected at least at lower test concentrations. Lower bioavailability cannot be excluded at higher test concentrations due to formation of larger agglomerates in the stock dispersion. The chemical composition of the nanomaterial, such as hydrophilic or hydrophobic coatings, is likely to influence the concentration at which the bioavailability and therefore the toxicity change from high to low. The total concentration in soil is determined by the maximum water holding capacity of a soil and by the highest suitable concentration in the stock dispersion and will therefore depend on both the nanomaterial and the applied soil. Highly-concentrated stock dispersions show a greater tendency for sedimentation. Furthermore, modification of the nanomaterials due to the energy input for the preparation of the stock dispersions cannot be excluded.

The nature of the ecotoxicological effect of the nanomaterials was inhibitory in the case of plants (reduced growth) but stimulatory in the case of earthworm reproduction and microbial nitrogen transformation. In contrast, McShane [5] observed no impact on earthworm reproduction in tests using artificial and natural soils. The stimulation of earthworm reproduction and its seasonal dependency have been comprehensively discussed [38].

\section{Table 7 Pros and cons for wet and dry spiking}

\begin{tabular}{|c|c|c|}
\hline & Dry spiking & Wet spiking \\
\hline \multirow[t]{2}{*}{ Pros } & $\begin{array}{l}\text { - High concentrations } \\
\text { independent of test } \\
\text { material }\end{array}$ & $\begin{array}{l}\text { - Higher bioavailability at least } \\
\text { at lower test concentrations }\end{array}$ \\
\hline & $\begin{array}{l}\text { - Procedure independent } \\
\text { of test concentration }\end{array}$ & \\
\hline \multirow[t]{3}{*}{ Cons } & - Reduced bioavailability & $\begin{array}{l}\text { - Functionalization of surface } \\
\text { by stirring / sonication }\end{array}$ \\
\hline & & $\begin{array}{l}\text { - Test concentrations comparably } \\
\text { low (limitation: } \mathrm{WHC}_{\max } \\
\text { sedimentation of nanomaterials } \\
\text { in stock dispersion) }\end{array}$ \\
\hline & & $\begin{array}{l}\text { - Agglomeration at higher } \\
\text { concentrations of stock suspension } \\
\text { can limit bioavailability; behavior } \\
\text { differs according to material }\end{array}$ \\
\hline
\end{tabular}

A transient reduction in microbial activity is often observed following an environmental insult and the subsequent overstimulation and return to normal activity reflects an adaptive response in the microbial population. As specified in the test guideline [23], we determined the nitrate concentration in the incubation vessels at only two time points, i.e. $3 \mathrm{~h}$ and 28 days after application. Nitrate generated in the incubation vessels is not consumed under the test conditions, thus a net increase at the test end-point indicates an increase in microbial nitrification activity during the 4-week incubation period. It is unclear whether there is still a difference in microbial activity between experimental and control vessels after the incubation period of 28 days. More detailed data on the effects of nanomaterials on microbial nitrification activity in the soil were outside the scope of this investigation, and would require additional sampling time points that are not currently mandated for the testing of non-agrochemicals. Additional data could also be produced by including modified tests, such as the determination of potential ammonium oxidation activity [24].

\section{Conclusions}

Our experiments using uncoated $\mathrm{TiO}_{2}$ and $\mathrm{Ag}$ nanoparticles showed that the application technique influences the severity of the effects observed in standardized ecotoxicity tests. The differences we detected were not dependent on either the direction of the effects (inhibition or stimulation) or on the test organisms, which represented different habitats and exposure pathways.

\section{Wet and dry spiking}

The most significant difference in ecotoxicological impact was observed when comparing wet and dry spiking methods. Wet spiking resulted in stronger effects than dry spiking. The effects caused by dry spiking were concentration-dependent for the selected test concentrations (3-6 concentrations, depending on the test) whereas there was no such relationship for the two test concentrations when wet spiking methods were applied using water as the carrier. Lower wet spiking concentrations than those reported here may have resulted in concentrationeffect curves. Higher test concentrations do not seem to be appropriate because the bioavailability of the particles appeared to be limited when highly-concentrated nanoparticle suspensions were used for wet spiking. Therefore, concentration-dependent effect curves are more difficult to obtain for wet application methods compared to dry spiking because the appropriate range of test concentrations has to be selected. The use of highly-concentrated stock suspensions could generate false negative results and incorrect hazard assessments. Limit tests investigating a single high test concentration are therefore inappropriate for wet 
spiking. Dry spiking is the preferred application method for solid, uncoated $\mathrm{TiO}_{2}$ and $\mathrm{Ag}$ nanoparticles to ensure the effects are not dependent on the particle concentration used for spiking, even though the bioavailability is reduced by the dry spiking method. Satisfactory test substance homogeneity can be achieved using a solid carrier, at least for Ag. If wet application is necessary, then further experiments will be required to establish parameters for successful use, e.g. the use of dispersants that are more suitable than water or recommendations on the procedure to select suitable test concentrations.

\section{Silica sand and air dried soil as solid carriers}

Silica sand reduced the bioavailability of the test substances compared to dried soil, but a wider range of carrier materials (different grades of silica sand and different soil types) will need to be tested to determine whether the observed differences are universal in character.

\section{Spiking soil and food}

We found no significant difference in earthworm reproduction when the test substances were applied in spiked soil and spiked food. The bioavailable concentrations of uncoated $\mathrm{TiO}_{2}$ for earthworms seem to be comparable regardless of whether exposure is via food or soil. The standardized test guidelines recommend soil spiking and this is also the method of choice for the testing of nanomaterials because the soil is distributed throughout the test vessel whereas the food is concentrated at the surface. The use of spiked soil prevents the extent of exposure being influenced by avoidance behavior. However, exposure via food is recommended if specific information on this pathway is required.

\section{Methods}

Test soil

We carried out our experiments using the reference soil RefeSol 01A (sieved $\leq 2 \mathrm{~mm}$ ) as both the test and carrier soil [39]. RefeSol 01A is a loamy, medium-acidic and lightly humic sand (Table 8). RefeSol soils were selected

\section{Table 8 Physicochemical properties of RefeSol 01A soil}

\begin{tabular}{ll}
\hline Physicochemical properties & RefeSol 01A \\
\hline $\mathrm{pH}$ & 5.67 \\
\hline $\mathrm{C}_{\text {org }}[\%]$ & 0.93 \\
\hline $\mathrm{N}_{\text {all }}[\mathrm{mg} / \mathrm{kg}]$ & 882 \\
\hline $\mathrm{CEC}_{\text {eff }}^{1}[\mathrm{mmolc} / \mathrm{kg}]$ & 37.9 \\
\hline Sand [\%] & 71 \\
\hline Silt [\%] & 24 \\
\hline Clay [\%] & 5 \\
\hline $\mathrm{WHC}_{\max }^{2}\left[\mathrm{ml} \mathrm{H} \mathrm{H}_{2} \mathrm{O} / \mathrm{kg}\right]$ & 227 \\
\hline
\end{tabular}

${ }^{1} \mathrm{CEC}$ : cation exchange capacity; ${ }^{2} \mathrm{WHC}_{\text {max }}$ : maximum water-holding capacity. as reference soils on behalf of the German Federal Environment Agency (Umweltbundesamt UBA) and they are known to be suitable for testing the influence of substances on the habitat function of soils (bioavailability, effects on organisms). RefeSol 01A matches the properties stated in various OECD terrestrial ecotoxicological guidelines (e.g. tests with plants and soil microflora). The soils were sampled in the field and stored in highgrade stainless steel basins with drainage and ground contact in the grounds of the Fraunhofer IME in Schmallenberg. During all our experiments, red clover was sown on the stored soils and no pesticides were used. Appropriate amounts of soil were sampled 1-4 weeks before the test. If the soil was too wet for sieving, it was dried at room temperature to $20-30 \%$ of the maximum water holding capacity $\left(\mathrm{WHC}_{\max }\right)$ with periodic turning to avoid surface drying. If the tests did not start immediately after sieving, the soil was stored in the dark at $4^{\circ} \mathrm{C}$ under aerobic conditions [40].

\section{Nanoparticle properties}

Most experiments were performed with P25, which is used in the Sponsorship Programme on the Testing on Manufactured Nanomaterials launched by the Working Party on Manufactured Nanomaterials (WPMN), which was established by the Chemicals Committee of the Organisation of Economic Cooperation and Development (OECD). The WPMN agreed on a priority list of nanomaterials and a list of endpoints relevant for environmental safety testing. A detailed description of P25 is presented by Schlich et al. [38] but major characteristics include anatase/rutile crystal structure, a primary particle size of 21 nm, a composition $>99 \% \mathrm{TiO}_{2}$, a Brunauer Emmet-Teller (BET) surface of $60 \mathrm{~m}^{2} / \mathrm{g}$ and no coating. The $\mathrm{TiO}_{2}$ nanoparticles we used have photocatalytic properties but these are not likely to affect their toxicity in soil because the energy input from illumination is missing. Additional experiments were carried out using commercially-available silver nanoparticles (Sigma-Aldrich silver nanopowder, catalog number 576832). The particle size was $<100 \mathrm{~nm}$, the purity $99.5 \%$ metal, and the surface area $5.0 \mathrm{~m}^{2} / \mathrm{g}$. In contrast to $\mathrm{TiO}_{2}$, silver nanoparticles release ions that are highly reactive and avidly bind to organic structures such as proteins, DNA and RNA, causing structural changes or inhibiting replication.

\section{Application methods}

Almost all ecotoxicological tests were carried out using spiked soils. A small number of earthworm tests were carried out with spiked food.

\section{Spiking soil with solid nanoparticles using soil as the carrier} The $\mathrm{TiO}_{2}$ and $\mathrm{Ag}$ nanoparticles were applied by mixing the powdered test material and air-dried carrier soil with 
the same physicochemical properties as the test soil (Table 8). Enough $\mathrm{TiO}_{2}$ powder was added to the carrier so that the correct final test concentration was achieved when $1 \%$ carrier soil and $99 \%$ test soil were mixed to homogeneity (see below). The soil was mixed with a spoon rather than a pestle to avoid modifying the $\mathrm{TiO}_{2}$ crystalline structure. Untreated soil (at 20-30\% $\mathrm{WHC}_{\max }$ ) was spread on a plate and the spiked carrier soil was evenly distributed over the test soil before manual mixing. The mixed soil was adjusted to 55\% $\mathrm{WHC}_{\max }$ using deionized water. Different test concentrations were applied depending on the test organism:

Plants (Avena sativa; oat) - $\mathrm{TiO}_{2}: 10,20,30,44,67$ and $100 \mathrm{mg} / \mathrm{kg}$ soil dry mass (dm).

Soil microflora (nitrogen transformation) $-\mathrm{TiO}_{2}$ : 9.3,

21, 45 and $100 \mathrm{mg} / \mathrm{kg}$ soil $\mathrm{dm}$.

Soil microflora (ammonium oxidation activity) - Ag: 10 and $100 \mathrm{mg} / \mathrm{kg}$ soil $\mathrm{dm}$.

Earthworms (Eisenia fetida) - $\mathrm{TiO}_{2}: 50,100$ and 200

$\mathrm{mg} / \mathrm{kg}$ soil dm.

\section{Spiking soil with solid nanoparticles using silica sand as the carrier}

We used the procedure described above, replacing the air-dried soil with silica sand as used in the building trade, with a particle size of up to $0.5 \mathrm{~mm}$ and a specific surface area of $89 \mathrm{~cm}^{2} / \mathrm{g}$. The same silica sand has been used for tests with artificial soil as described e.g. in OECD test guideline 222 [21]. The procedure was used to measure microbial ammonium oxidation activity with Ag concentrations of 10 and $100 \mathrm{mg} / \mathrm{kg}$ soil dm.

\section{Spiking soil with aqueous nanoparticle dispersions}

A dispersion of $\mathrm{TiO}_{2}$ nanoparticles was prepared by homogenizing a specific mass of particles in deionized water with a magnetic flea (900 rpm for $1 \mathrm{~min}$ ) followed by ultrasonication (3 $\mathrm{min}$ ) in a bath sonicator [18]. The test soil was dried to $\sim 10 \% \mathrm{WHC}_{\max }$ and spread on a plate. The full dose of $\mathrm{TiO}_{2}$ dispersion (enough to achieve the required test concentration in one application) was sprayed onto the soil using a syringe coupled to a cannula, and mixed thoroughly. Following the application of the dispersion and additional water used to clean the syringe, the test soil was adjusted to $55 \% \mathrm{WHC}_{\max }$. The concentrations of the dispersions were made up to 95 and $187 \mathrm{mg} / \mathrm{L}$ in a total volume of $500 \mathrm{~mL}$ deionized water. Approximately $262 \mathrm{ml}$ of test dispersion was added to $2.5 \mathrm{~kg}$ of test soil dm to increase the WHC from $\sim 10 \%$ to $55 \%$, corresponding to 10 and $20 \mathrm{mg} / \mathrm{kg} \mathrm{dm}$ doses. For tests with soil microflora (nitrogen transformation), the final concentrations were 9.3 and $21 \mathrm{mg} / \mathrm{kg}$ soil $\mathrm{dm}$.

\section{Spiking food with solid nanoparticles}

We mixed $40 \mathrm{~g}$ of air-dried, ground cow manure from an organic farm (enough for four replicates per test concentration) with the appropriate amount of $\mathrm{TiO}_{2}$ powder to achieve 50, 100 and $200 \mathrm{mg} / \mathrm{kg}$ final test concentrations, and divided the homogeneous mixture into four aliquots of $10 \mathrm{~g}$. The mixture was moistened with 120 $\mathrm{ml}$ deionized water and $40 \mathrm{~g}$ of moist food was placed on the soil surface in 1-L test containers. The total amount of $\mathrm{TiO}_{2}$ per test vessel was the same in the spiked food and spiked soil experiments.

\section{Spiking food with aqueous nanoparticle dispersions}

We mixed $40 \mathrm{~g}$ of air-dried, ground cow manure with $120 \mathrm{ml}$ concentrated $\mathrm{TiO}_{2}$ dispersions (212 and $424 \mathrm{mg} /$ $\mathrm{L}$ in deionized water, in a total volume of $500 \mathrm{~mL}$, prepared by stirring at $900 \mathrm{rpm}$ for $1 \mathrm{~min}$ and ultrasonication for $3 \mathrm{~min}$ ). The dung was applied to $2.5 \mathrm{~kg} \mathrm{dm}$ soil, corresponding to soil concentrations of 10 and $20 \mathrm{mg} / \mathrm{kg}$ soil $\mathrm{dm}$.

\section{Ecotoxicological tests}

All tests were carried out as recommended in the corresponding OECD test guidelines. The earthworm reproduction test with Eisenia fetida [21] permits the use of Eisenia fetida or Eisenia andrei as test organisms. We used Eisenia andrei which has been cultured in our laboratory for more than 15 years. The earthworms were acclimated to the test soil for 7 days prior to testing. We filled polypropylene containers (Bellaplast $\mathrm{GmbH}$, Alf) to a depth of $\sim 5 \mathrm{~cm}$ with $640 \mathrm{~g}$ dry mass of soil $\left(55 \% \mathrm{WHC}_{\max }\right)$ and then spread $40 \mathrm{~g}$ wet cow manure (10 g air-dried cow manure, ground and moistened before application) onto the surface. The cows were kept in an ethical husbandry. The tests comprised eight replicates for the control and four replicates for each $\mathrm{TiO}_{2}$ concentration.

Ten earthworms weighing between 300 and $450 \mathrm{mg}$ were added to each container, and the containers were incubated at $20 \pm 2^{\circ} \mathrm{C}$ with a light/dark cycle of $16 / 8 \mathrm{~h}$ ( 700 lux). Once per week, the water content was checked gravimetrically and evaporated water was replaced. Every 7 days, $20 \mathrm{~g}$ (wet weight corresponding to $5 \mathrm{~g}$ dry weight) of uncontaminated food was spread on the soil surface in each container. After 28 days, the adult earthworms were removed and weighed, and after 56 days the number of juveniles in each test container was counted.

Oat seedlings (Avena sativa) [22] were cultivated in round nonporous plastic containers $85-95 \mathrm{~mm}$ in diameter. A glass fiber wick drew water from a reservoir through the bottom of the container to ensure consistent soil moisture. The water contained $1 \mathrm{~mL} / \mathrm{L}$ fertilizer (Floragard Vertriebs GmbH, Oldenburg, Germany). The nutrient content of the fertilizer was ammonium $23 \mathrm{mg} / \mathrm{L}$, iron 
(chelate) $0.50 \mathrm{mg} / \mathrm{L}$, nitrate $23 \mathrm{mg} / \mathrm{L}$, copper (chelate) 0.30 $\mathrm{mg} / \mathrm{L}$, phosphate $30 \mathrm{mg} / \mathrm{L}$, manganese (chelate) 0.30 $\mathrm{mg} / \mathrm{L}$, potassium oxide $60 \mathrm{mg} / \mathrm{L}$, molybdenum $0.01 \mathrm{mg} / \mathrm{L}$, zinc (chelate) $0.05 \mathrm{mg} / \mathrm{L}$ and boron $0.10 \mathrm{mg} / \mathrm{L}$. The containers were filled with approximately $280 \mathrm{~g}$ of moist soil (about $55 \%$ of $\mathrm{WHC}_{\max }$ ). Five seeds of the same size were planted in each replicate container immediately after spiking, and $24 \mathrm{~h}$ later the wicks were connected to the reservoir to moisten the soil. The test was carried out in a plant growth chamber at $20 \pm 2^{\circ} \mathrm{C}, 70 \pm 25 \%$ humidity and with a 16-h photoperiod (light intensity $>7000$ lux, color 25 universal white).

The 14-day growth phase started when $50 \%$ of the seedlings in the control group had emerged (growth day 1). The number of emerged seedlings was recorded in all containers. Emergence and visual signs of phytotoxicity and mortality were recorded throughout the exposure period. On growth day 14, all seedlings were counted and the aboveground wet biomass of the plants was measured immediately after harvesting.

For the nitrogen transformation test with soil microflora [23] we augmented sieved and spiked soil with powdered plant material (lucerne-grass-green meal) at a plant/soil ratio of $5 \mathrm{~g}$ plant per kilogram of soil (dry mass). Three incubation containers per treatment were filled with $658 \mathrm{~g}$ of spiked soil along with three matching controls. The test was carried out in darkness at $20 \pm 2^{\circ} \mathrm{C}$ for 28 days, during which the moisture content of the soil was maintained at $40-60 \%$ of $\mathrm{WHC}_{\max }$ with a maximum range of $5 \%$. The mass in the test vessels was measured weekly. Evaporated water was replaced with deionized water.

Samples of each treated and control vessel were analyzed for nitrate content at the beginning ( $3 \mathrm{~h}$ after application, day 0) and at the end of the exposure period (28 days). Nitrate was extracted from soil by shaking samples $(20 \mathrm{~g} \mathrm{dm})$ with $0.1 \mathrm{M} \mathrm{KCl}$ solution at a ratio of $5 \mathrm{~mL}$ of $\mathrm{KCl}$ solution per gram dry weight for $60 \mathrm{~min}$ at $150 \mathrm{rpm}$. The mixtures were filtered and the liquid phases were analyzed for nitrate photometrically (Spectroquant ${ }^{\circledR}$ NOVA 400) immediately after preparing each extract. The nitrate concentration on days 0 and 28 was used to calculate the nitrogen transformation rate.

The short-term potential ammonium oxidation test [24] was carried out using sieved and spiked soil. Four 250-mL Erlenmeyer flasks per treatment were filled with $25 \mathrm{~g} \mathrm{dm}$ of spiked soil along with four matching controls. The vessels were incubated in darkness at $20 \pm 2^{\circ} \mathrm{C}$ for $24 \mathrm{~h}$ and then mineral test medium was added to make up the volume to $100 \mathrm{~mL}$. The medium consisted of $\mathrm{KH}_{2} \mathrm{PO}_{4}(0.56 \mathrm{mM}), \mathrm{K}_{2} \mathrm{HPO}_{4}$ (1.44 mM), $\mathrm{NaClO}_{3}$ (5 mM), $\left(\mathrm{NH}_{4}\right)_{2} \mathrm{SO}_{4}(1.50 \mathrm{mM})$. The slurries were incubated on an orbital shaker at $25 \pm 2^{\circ} \mathrm{C}$, and $10-\mathrm{mL}$ samples were removed after 2 and $6 \mathrm{~h}$, supplemented with $10 \mathrm{~mL} 4 \mathrm{~mol} / \mathrm{L} \mathrm{KCl}$, filtered and nitrite levels in the filtrate were determined photometrically.

Statistical analysis was carried out using ToxRat ${ }^{\circledR}$ Pro v2.10 software for ecotoxicity response analysis (ToxRat $^{\circledR}$ Solutions GmbH, Alsdorf, Germany).

\section{Determination of Ag levels}

Digestion was carried out according to standardized guidelines $[41,42]$ using soil dried at $105^{\circ} \mathrm{C}$ for at least $12 \mathrm{~h}$ until it reached a constant weight. Approximately $3 \mathrm{~g}$ of the homogenized material was mixed with $28 \mathrm{~g}$ of aqua regia and incubated at room temperature for $16 \mathrm{~h}$ without agitation. The mixture was then heated under reflux for $2 \mathrm{~h}$ with glass chips and 1-octanole added to avoid overboiling and foaming. The mixture was cooled to room temperature, carefully made up to $100 \mathrm{~mL}$ and filtered $(0.45 \mu \mathrm{m}$ syringe filter, polyethersulfon membrane, Pall Corporation, New York). The concentration of silver was determined by inductively coupled plasma optical emission spectrometry (ICPOES) using an IRIS Intrepid II (Thermo Electron, Dreieich, Germany) with a matrix-adjusted calibration carried out before each measurement. Silver was detected at $328.068 \mathrm{~nm}$ and compared to the certified reference material TMDA-70 (certified with $10.9 \mu \mathrm{g} / \mathrm{L}$ $\mathrm{Ag}$ ) as a quality assurance sample. According to the quality assurance requirement, the silver recovery was in the range of $\pm 15 \%$ of the certified value. However, regarding Ag concentrations measured by ICP-OES, the mean recovery (accuracy) and precision of the non-digested CRM TMDA-70 measurements was 101 $\pm 2.9 \%(\mathrm{n}=4)$. The recovery for Merck IV standard solution samples containing $50 \mu \mathrm{g} / \mathrm{L}$ was $101 \pm 2.7 \%$ $(\mathrm{n}=4)$ and $94.7 \pm 0.7 \%$ for $500 \mu \mathrm{g} / \mathrm{L}$. Silver concentrations in reagent blanks were always below the limit of detection in the corresponding measurement series.

\section{Competing interests}

The authors declare that they have no competing interests.

\section{Authors' contributions}

KHR participated in the design of the study, drafted the manuscript. KS performed all experiments and was involved in drafting the manuscript. TK was responsible for the chemical analysis. All authors read and approved the final manuscript.

\section{Acknowledgements}

This study was developed in the context of the OECD Sponsorship Programme for the safety testing of nanomaterials. It was carried out on behalf of the German Federal Environment Agency (FKZ 370965 416) and financed by federal funds.

Received: 8 June 2012 Accepted: 10 October 2012

Published: 17 October 2012

\section{References}

1. ENV/JM/MONO(2009)21 (10-Jul-2010): Preliminary Review of OECD Test Guidelines for their Applicability to Manufactured Nanomaterials. OECD 
Environment, Health and Safety Publications Series on the Safety of Manufactured Nanomaterials. 15th edition. 2009 [http://www.oecd.org/ document/53/0,3746,en_2649_37015404_37760309_1_1_1_1,00.html].

2. ENV/JM/MONO(2010)25) (31-May-2010): Preliminary Guidance Notes on Sample Preparation and Dosimetry for the Safety Testing of Manufactured Nanomaterials. 24th edition. [http://www.oecd.org/document/53/0,3746, en_2649_37015404_37760309_1_1_1_1,00.html].

3. Tong Z, Bischoff M, Nies L, Applegate B, Turco RF: Impact of fullerene (C60) on a soil microbial community. Environ Sci Technol 2007, 41:2985-2991.

4. Johansen A, Pedersen AL, Jensen KA, Karlson U, Hansen BM Scott-Fordsmand JJ, Winding A: Effects of $C_{60}$ fullerene nanoparticles on soil bacteria and protozoans. Environ Toxicol Chem 2008, 27:1895-1903.

5. McShane H, Sarrazin M, Whalen JK, Hendershot WH, Sunahara Gl: Reproductive and behavioral response of earthworms exposed to nano-sized titanium dioxide in soil. Environ Toxicol Chem 2012, 31:184-193.

6. Whitfiel Aslund ML, MCShane H, Simpson MJ, Simpson AJ, Whalen JK, Hedershot WH, Sunahara Gl: Earthworm sublethal responses to titanium dioxide nanomaterial in soil detected by ${ }^{1} \mathrm{H}$ NMR metabolomics. Environ Sci Technol 2012, 46:1111-1118.

7. Ge Y, Schimel JP, Holden PA: Evidence for negative effects of $\mathrm{TiO}_{2}$ and $\mathrm{ZnO}$ nanoaprticles on soil bacterial communities. Environ Sci Technol 2011, 45:1659-1664.

8. Lapied E, Nahmani JY, Moudilou E, Cjaurand P, Labille J, Rose J, Exbrayat J-M, Oughton DJ, Joner EJ: Ecotoxicological effects of an aged TiO2 nanocomposite measured as apoptosis in the anecic earthworm Lumbricus terrestris after exposure through water, food and soil. Environ Int 2011, 37:1105-1110.

9. Scott-Fordsmand JJ, Krogh PH, Schaefer M, Johansen A: The toxicity testing of double-walled nanotubes-contaminated food to Eisenia veneta earthworms. Ecotox Environ Safety 2008, 71:616-619.

10. Hu CW, Li M, Cui YB, Li DS, Chen J, Yang LY: Toxicological effects of $\mathrm{TiO}_{2}$ and $\mathrm{ZnO}$ nanoparticles in soil on earthworm Eisenia fetida. Soil Biol Biochem 2010, 42:586-591.

11. Coleman JG, Johnson DR, Stanley JK, Bednar AJ, Weiss CA Jr, Boyd RE, Steevens JA: Assessing the fate and effects of nano aluminium oxide in the terrestrial earthworm, Eisenia fetida. Environ Toxicol Chem 2010, 29:1575-1580.

12. Du W, Sun Y, Ji R, Zhu J, Wu J, Guo H: $\mathrm{TiO}_{2}$ and $\mathrm{ZnO}$ nanoparticles negatively affect wheat growth and soil enzyme activities in agricultural soil. J Environ Monit 2011, 13:822-828.

13. French RA, Jacobson AR, Kim B, Isley SL, Penn RL, Baveye PC: Influence of ionic strength, $\mathrm{pH}$ and cation valence on aggregation kinetics of Titanium Dioxide nanoparticles. Environm Sci Technol 2008, 43:1354-1359.

14. Boncagni NT, Otaegui JM, Warner E, Curran T, Ren J, Cortalezzi MM: Exchange of $\mathrm{TiO}_{2}$ Nanoparticles between Streams and Streambeds. Environm Sci Technol 2009, 43:7699-7705.

15. Mukherjee B, Weaver JW: Aggregation and charge behavior of metallic and nonmetallic nanoparticles in the presence of competing similarly charged inorganic ions. Environm Sci Technol 2010, 44:3332-3338.

16. Ottofuelling $S$, von der Kammer $F$, Hofmann T: Commercial titanium dioxide nanoparticles in both natural and synthetic water: comprehensive multidimensional testing and prediction of aggregation behavior. Environm Sci Technol 2011, 45:10045-10052.

17. Cumberland SA, Lead JR: Particle size distributions of silver nanoparticles at environmentally relevant conditions. J Chromatogr A 2009, 1216:9099-9105.

18. Hund-Rinke $\mathrm{K}$, Schlich $\mathrm{K}$, Wenzel $\mathrm{A}: \mathrm{TiO}_{2}$ nanoparticles - Relationship between dispersion preparation method and ecotoxicity in the algal growth test. Umweltwiss Schadst Forsch 2010, 22:517-528.

19. Römer I, White TA, Baalousha M, Chipman K, Viant MR, Lead JR: Aggregation and dispersion of silver nanoparticles in exposure media for aquatic toxicity tests. J Chromatogr A 2011, 1218:4226-4233.

20. Manier N, Garaud M, Delalain P, Aguerre-Chariol O, Pandard P: Behaviour of ceria nanoparticles in standardized test media - influence on the results of ecotoxicological tests. J. Phys.: Conf. Ser. 304th edition. 2011:012058. doi:10.1088/1742-6596/304/1/012058.

21. OECD Guideline for the Testing of Chemicals Test No. 222, 2004. Earthworm Reproduction Test (Eisenia fetida/Eisenia andrei). 2004.

22. OECD Guideline for the Testing of Chemicals Test No. 208, 2006. Terrestrial Plant Test: Seedling Emergence and Seedling Growth Test. 2006.
23. OECD Guideline for the Testing of Chemicals Test No. 216, 2000. Soil Microorganisms: Nitrogen Transformation Test. 2010.

24. ISO 15685, 2004. Soil quality - Determination of potential nitrification and inhibition of nitrification - Rapid test by ammonium oxidation. 2004.

25. Gottschalk F, Sonderer T, Scholz RW, Nowack B: Modeled Environmental concentrations of engineered nanomaterials (TiO2, $\mathrm{ZnO}, \mathrm{Ag}, \mathrm{CNT}$, Fullerenes) for different Regions. Environ Sci Technol 2009, 43:9216-9222.

26. European Chemicals Agency (ECHA): Guidance on information requirements and chemical safety assessment: Chapter R.10: characterisation of dose [concentration]-response for environment. 2008 [http://echa.europa.eu/ documents/10162/17224/information_requirements_r10_en.pdf].

27. Fareé M, Sanchís J, Barceló D: Analysis and assessment of the occurrence, the fate and the behavior of nanomaterials in the environment. Trends Anal Chem 2011, 30:517-527.

28. Von der Kammer F, Ferguson PL, Holden PA, Masion A, Rogers KR, Klaine SJ, Koelmans AA, Horne N, Unrine JM: Analysis of engineered nanomaterials in complex matrices (environment and biota): General considerations and conceptual case studies. Environ Toxicol Chem 2012, 31:32-49.

29. Lee WM, Ha SW, Yang CY, Lee JK, An YJ: Effect of fluorescent silica nanopartilces in embryo and larva of Oryzias latipes: Sonic effect in nanoparticle dispersion. Chemosphere 2011, 82:451-459.

30. Gaiser BK, Fernandes TF, Jepson MA, Lead JR, Tyler CR, Baalousha M, Biswas A, Britton GJ, Cole PA, Johnston BD, Ju-Nam Y, Rosenkranz P, Scown TM, Stone $\mathrm{V}$ : Interspecies comparsons on the uptake and toxicity of silver and cerium dioxide nanoparticles. Environ Toxicol Chem 2012, 31:144-154.

31. Kim SW, Nam SH, An YJ: Interaction of silver nanoparticles with biological surfaces of Caenorhabditis elegans. Ecotox Environ Safety 2012, 77:64-70.

32. van der Ploeg MJC, Baveco JM, van der Hout A, Bakker R, Rietjens IMCM, van den Brink N: Effects of C60 nanoparticle exposure on earthworms (Lumbricus rubellus) and implications for population dynamics. Environ Pollut 2011, 159:198-203.

33. Kool PL, Ortiz MD, van Gestel CAM: Chronic toxicity of $\mathrm{ZnO}$ nanoparticles, non-nano $\mathrm{ZnO}$ and $\mathrm{ZnCl} 2$ to Folsomia candida (Collembola) in relation to bioavailability in soil. Environ Pollut 2011, 159:2713-2719.

34. ISO 21268-1, 2007: Soil quality - Leaching procedures for subsequente chemical and ecotoxicological testing of soil and soil materials - Part 1: Batch test using a liquid to solid ration of $2 \mathrm{l} / \mathrm{kg}$ dry matter. 2007.

35. Schreck E, Foucoult $Y$, Geret F, Pradere P, Dumat C: Influence of soil ageing on bioavailability and ecotoxicity of lead carried by process waste metallic ultrafine particles. Chemosphere 2011, 85:1555-1562.

36. Donner E, Broos K, Heemsbergen D, Warne MSJ, McLaughlin MJ, Hodson ME, Nortcliff S: Biological and chemical assessments of zinc ageing in field soils. Environ Pollut 2010, 158:339-345.

37. Shoults-Wilson WA, Zhurbich OI, McNear DH, Tsyusko OV, Bertsch PM, Unrine JM: Evidence for avoidance of Ag nanoparticles by earthworms (Eisenia fetida). Ecotoxicology 2011, 20:385-396.

38. Schlich $\mathrm{K}$, Terytze $\mathrm{K}$, Hund-Rinke $\mathrm{K}$ : Effect of $\mathrm{TiO}_{2}$ nanoparticles in the earthworm reproduction test. Environ Sci Eur 2012, 24:5.

39. IME RefeSol. [http://www.refesol.de].

40. ISO 18512, 2007. Soil Quality - Guidance on Long and Short Term Storage of Soil Samples. 2007

41. DIN ISO 11466, 1997. Extraction of trace elements soluble in aqua regia. (ISO 11466:1995). 1997.

42. DIN EN 13346, 2001. Characterization of suldges - Determination of trace elements and phosphorus - Aqua regia extraction methods. (EN 13346:2000). 2001

\section{doi:10.1186/2190-4715-24-30}

Cite this article as: Hund-Rinke et al.: Influence of application techniques on the ecotoxicological effects of nanomaterials in soil. Environmental Sciences Europe 2012 24:30. 